\title{
Mining and Historical Capitalism
}

\author{
A Review \\ Leonardo Marques
}

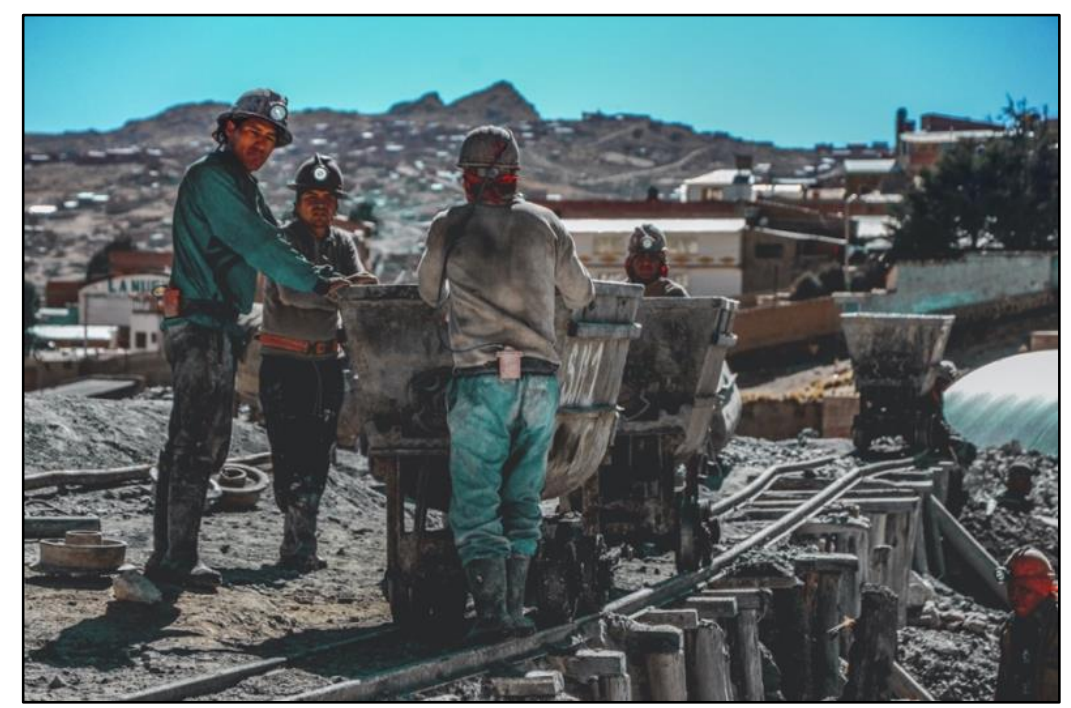

Photo source: Pedro Henrique Santos on Upsplash

Books reviewed: Horacio Machado Aráoz, Mineração, genealogia do desastre. São Paulo: Editora Elefante, 2020; Martín Arboleda, Planetary Mine: Territories of Extraction under Late Capitalism. London: Verso, 2020.

$\mathrm{F}$ rom smartphones to so-called green technologies, including Elon "We will coup whoever we want" Musk's electric cars, the production of many contemporary commodities continues to depend on the extraction of various raw materials from different parts of the world. Salar del Carmen, in Chile, for example, produces around 48,000 tons of lithium a year, a volume that could be used to produce 43 billion iPhones (Arboleda, p.76). The centrality of mining to modern life - a theme that appears in the two books reviewed here - can be found in "those unspectacular, nearly imperceptible practices and habits that constantly weave together the fabric of everyday life in the twenty-firstcentury city: sending an email, driving to work, ordering groceries through the internet" (Arboleda, p.13). This urban experience appears to us in fragmented and ahistorical forms, something that the analysis of mining commodity chains helps dissipate, as these books show. From

\section{Correspondence:}

Leonardo Marques, $\underline{\operatorname{lm} @ \text { id.uff.br }}$

Cite this article:

Marques, L. 2020. "Mining and Historical Capitalism: A Review." Commodity Frontiers 1: 48-52. doi: 10.18174/CF.2020a17970.

Commodity Frontiers is an open-access journal edited by the CFI Editorial Board, Mindi Schneider, senior editor. Read it online at Commodity Frontiers, or our website, commodityfrontiers.com.

This work is licensed under a Creative Commons Attribution-NonCommercial 4.0 International License.

\section{(1) (8)}


violence against workers and militants to multiple environmental disasters, they offer detailed depictions of the impacts of mining enterprises in Latin America. In Mineração, genealogia do desastre [Mining, Genealogy of Disaster], Horácio Machado Araóz connects the colonial experience of Potosí to the broad expansion of mining in contemporary Latin America as a whole. In Planetary Mine, Martín Arboleda also makes important incursions into the longer history of extractivism in Latin America, but his focus is on recent transformations in northern Chile and their relationship to global economic developments, especially the rise of Asian nations. There is much in common in these two books, but also some clear differences, especially in their theoretical frameworks.

The core of Mineração, genealogia do desastre is the idea that mining in colonial Latin America is at the center of modernity. Historians of mining in Latin America have raised several questions about its relationship to the development of capitalism as a historical system. They have shown the highly modern aspects of mining enterprises since the sixteenth century, their social and environmental impacts in places like Potosí (perhaps the world's most commodified city by the late sixteenth century), and the importance of bullion flows to the development of the Old World, from the creation of a world economy to the development of Europe. Machado Araóz builds his argument using part of this scholarship and suggests that he is doing an archaeology of modernity by exploring two key archaeological sites: Santo Domingo and Potosí.

On Santo Domingo the reader learns very little; this section appears mainly as a strategy to discuss the emergence of a modern subject whose main motivation is greed, as evidenced by the European search for precious metals. His focus is really on Potosí and for good reason: this was by far the world's main source of silver in the long sixteenth century. The author describes the social and environmental consequences of mining in the Andes and the central role played by the Spanish state in its development. On the other side of the Atlantic, the Spanish state financed the war against other European states and contributed to the commodification of the modern raison d'État. The main contribution of the mining periphery, according to Machado Araóz, can be found in this articulation between the accumulation of capital, the financing of war, and the making of modern states. This is a powerful idea, but a number of additional aspects that would strengthen the argument could have been explored with a more careful look at the historiography, such as the role of precious metals in European financial developments (which appears but receives scant attention here) or the modernity of state practices in the periphery (such as in the counting of local populations for the mita).

Machado Araóz also offers an extended discussion of mining in the contemporary world. The recent Brazilian edition includes a preface and a postface by Brazilian scholars updating the discussion with references to the disasters of Mariana and Brumadinho, Minas Gerais. These are obviously only the last chapters of a long history of disasters and violence in all of Latin America and Machado Araóz does offer a comprehensive list of these events in the last section of his book. One of the most interesting (and tragic) aspects of this recent expansion of mining appears in the massive use of water by open-pit mining 
enterprises. By using much of the water from local reservoirs they affect local populations and their economic activities not only by limiting their access to water, but also by transforming hydrographic circuits and polluting such a vital resource in various ways. In Chile, the water code of 1981, passed under the Pinochet dictatorship, was a key step in all this, a process that appears in Machado Araóz's book but is described in more detail by Arboleda. In an excellent chapter, the latter shows the role of technocrats in the creation of the necessary structure for the expansion of mining in Chile and its use of water resources, a process that - surprise, surprise - had very little to do with free market mechanisms. Machado Araóz in turn explores this and other recent Latin American transformations largely based on David Harvey's concept of accumulation by dispossession, a concept that has been widely used in the scholarship on (neo)extractivism.

In theoretical terms, Machado Araóz draws on a large number of authors and traditions besides Harvey, from Michel Foucault to dependency theory and decolonial studies. The return to dependency theory is at times too crude and many of the arguments are more affirmed than substantiated by the data. There is a strong reaffirmation of the center-periphery divide, for example, but nothing on the more complex relations produced by the "economic space" of silver, as described by Carlos Sempat Assadourian (who nonetheless makes a few brief appearances in the text). A similar problem appears when discussing contemporary developments and the idea that "enclave economies" are becoming the norm in Latin America. In one of the book's tables (Machado Araóz, p.204), the author shows the role of mining in exports, in the GDP, and other aspects of the national economies of Chile, Peru, and Argentina. While minerals are responsible for $63 \%$ of all Chilean exports, in Argentina they amount to $2,55 \%$. This does not invalidate the thesis of a new extractivism, but it does point to some complicated aspects that tend to be neglected in such a broad overview of the region.

Moreover, the eclectic use of authors in the book does not always work. Araóz makes, for example, a critique of Dennis Flynn and his view that the Spanish expenditure on war was irrational, followed by a broader take on the historiography that tends to consider Spain a feudal, backward economy (Machado Araóz, p.158). This is an important critique, but at other moments he builds on Ellen Meiksins Wood's idea of an "Empire of Capital" (Ibidem, p. 89-90). Like many other authors within so-called "Political Marxism," Wood dismisses the history of the Iberian empires as feudal or non-capitalist. Recent efforts by scholars working within this tradition to understand slavery within the history of capitalism, such as David McNally's Blood and Money (2020), which appears in Arboleda's book, remain strikingly Anglocentric. By simply dismissing the Iberian empires as feudal (McNally has a few pages on them before moving from Antiquity to Modernity), these scholars have neglected the role played by extractivism in the mines and rivers of Latin America in the establishment of British hegemony within the capitalist world system in the long eighteenth century. In sum, the critique that Machado Araóz correctly makes for Flynn could be extended to a number of authors that he uses in his narrative (as does Arboleda, for that matter).

Finally, Machado Araóz's effort to show the centrality of mining to capitalist 
development also leads to some exaggerated statements that tend to obscure the more specific elements of this articulation. "In any of its modalities," he argues, "modern power, a form of domination that is historically specific and starts with modernity, cannot do without mining. The latter was born from and with colonialism." (Machado Araóz, p.179). Extractivism is indeed a key part of capitalism and has become increasingly central to modern life over the centuries, but it was not born with it. The argument only makes sense if the author is thinking along the lines of colonialism as a longer aspect of human history, but Jack Goody is not one of the references here. A similar problem appears in his discussion of greed as a guiding principle of the modern subject.

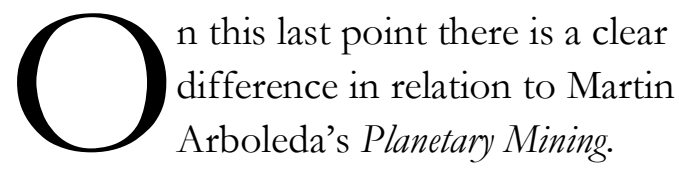

Unlike the conflation that at times appears in Machado Araóz, mining here is described as "not historically specific, and for this reason it has evolved alongside the modalities of personal dependence most characteristic of premodern societies (chattel slavery, pillage, feudal extortion, conquest, and so forth)" (Arboleda, p.172). Such a conception brings a different set of problems, especially the assignment of personal forms of violence and dependence to a sphere outside capitalism. This is also the basis of Arboleda's critique of some of the recent uses of the concepts of primitive accumulation and accumulation by dispossession. While sympathetic to these perspectives in that they show how violence is a key part in the constitution of capitalist property regimes, he ultimately thinks it necessary to analytically separate this from actual capitalism, which for him depends on purely economic forms of coercion. Here one of the main theoretical inspirations of the book becomes clear: the Marxist debate on value form theory, especially Moishe Postone's Time, Labor, and Social Domination (1993). This bibliography is usually very abstract and frequently appears largely disconnected from concrete realities. Arboleda (p.30) is aware of this when pointing out the distinction between an essential content of capitalism and its multiple historical appearances, and one of the many qualities of this book is the effort to actually bridge this chasm. But outlining the exact mediations between these different levels is not an easy task and at times Arboleda presents the empirical material as an automatic expression of the so-called real abstraction that is at the center of value form interpretations of capitalism. At the same time, he rejects the "Saint-Simonian moral reading $[\mathrm{s}]$ of primitive accumulation" that have emphasized violence and pointed fingers to specific companies and states. While he is making an important political point here (rejecting the idea that the state is a neutral vehicle that can be correctly guided if driven by the right pilot), it is not always clear why these historical manifestations are in contradiction to his emphasis on the capitalist world market or the real abstractions of capitalism.

Still, Planetary Mine is an impressive book in many different ways. While the literature on the new extractivism in Latin America describes the rise of China as one of the key motors of these recent transformations, Arboleda offers a more detailed and interesting take on this connection, outlining the main transformations within China itself that have generated this great hunger for primary resources from different parts of the world. The theoretical framework is also richer than many works on extractivism, despite some unresolved problems and 
tensions. Arboleda is at his best in a remarkable chapter on the relationship between global finances, resource extraction, and the production of urban environments in northern Chile based on Henri Lefebvre, whose concept of totality offers ways of understanding the dynamics of the local and the global, or "how the whole expresses itself through the part and how constant flux between parts reconfigures the whole" (Arboleda, p.178). One of the greatest strengths here is the move between different scales of observation, with the author constantly shifting his analysis between Antofagasta in northern Chile, Asian nations, and the capitalist world economy. Such a relational perspective could in fact help solve some of the problems outlined earlier in both books.

Let me conclude with one last comment on the relationship between mining and historical capitalism. As Arboleda argues, mining did not emerge with capitalism, but there is a clear difference between capitalist mining and pre-modern versions of the practice. A contrast with the capitalism and slavery debate could be helpful here: an institution from the ancient world that was nonetheless re-created by capitalism in the early modern era. These are not simply premodern institutions that are opportunistically explored by capital, as more traditional readings of merchant capital would have it; they are to a large extent capitalist reconstructions. Moreover, mining (like slavery) changes over time even in its capitalist forms. Machado Araóz hints at this when describing how industrial developments in the nineteenth and twentieth centuries led to an intensification of the demand for old and new minerals, with British and US capital increasingly spreading over Latin America in search of copper, zinc, tin, bauxite, iron, among other resources. Unfortunately, this line of inquiry is not developed further by the author, who sticks to his idea of an "archeology," moving from the colonial period to contemporary developments. Arboleda also hints at this when mentioning the long history of extractivism within capitalism based on the fundamental works of Stephen Bunker and Paul Ciccantell, who argue that each cycle of accumulation (an idea that is obviously indebted to Giovanni Arrighi's seminal work) is marked by technological changes that revolutionize transport and allow for greater access to both existing and new extractive frontiers. This is an excellent framework for understanding the role of mining within capitalism as a historical system that has changed over time.

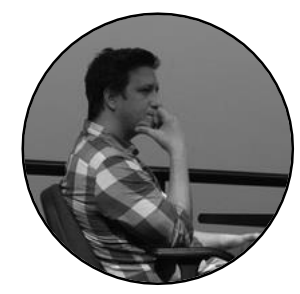

Leonardo Marques is professor of History at the Universidade Federal Fluminense (Brasil) and author of The United States and the Transatlantic Slave Trade to the Americas (1776-1867) (Yale University Press, 2016). He is currently working on a global history of gold and slavery. 